SJîñm Jurnal

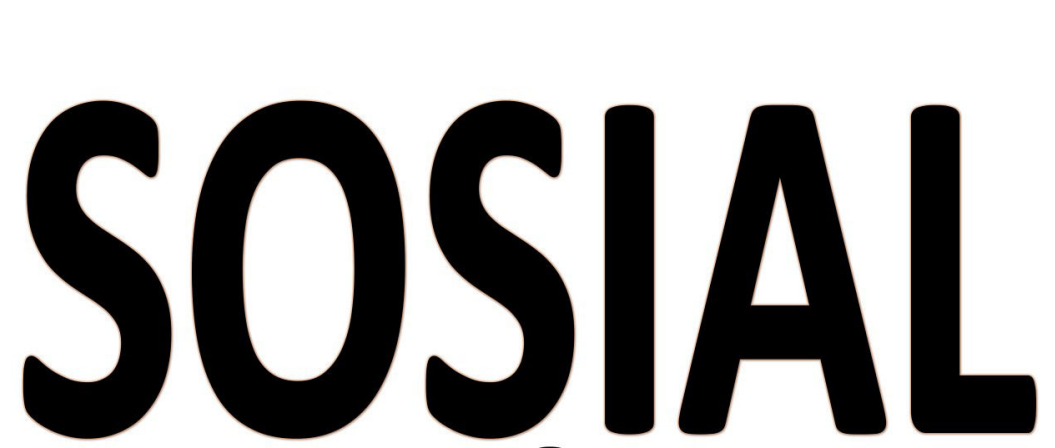

P-ISSN: 2356-1459 E-ISSN: 2654-9050 Vol. 7 No. 6 (2020)
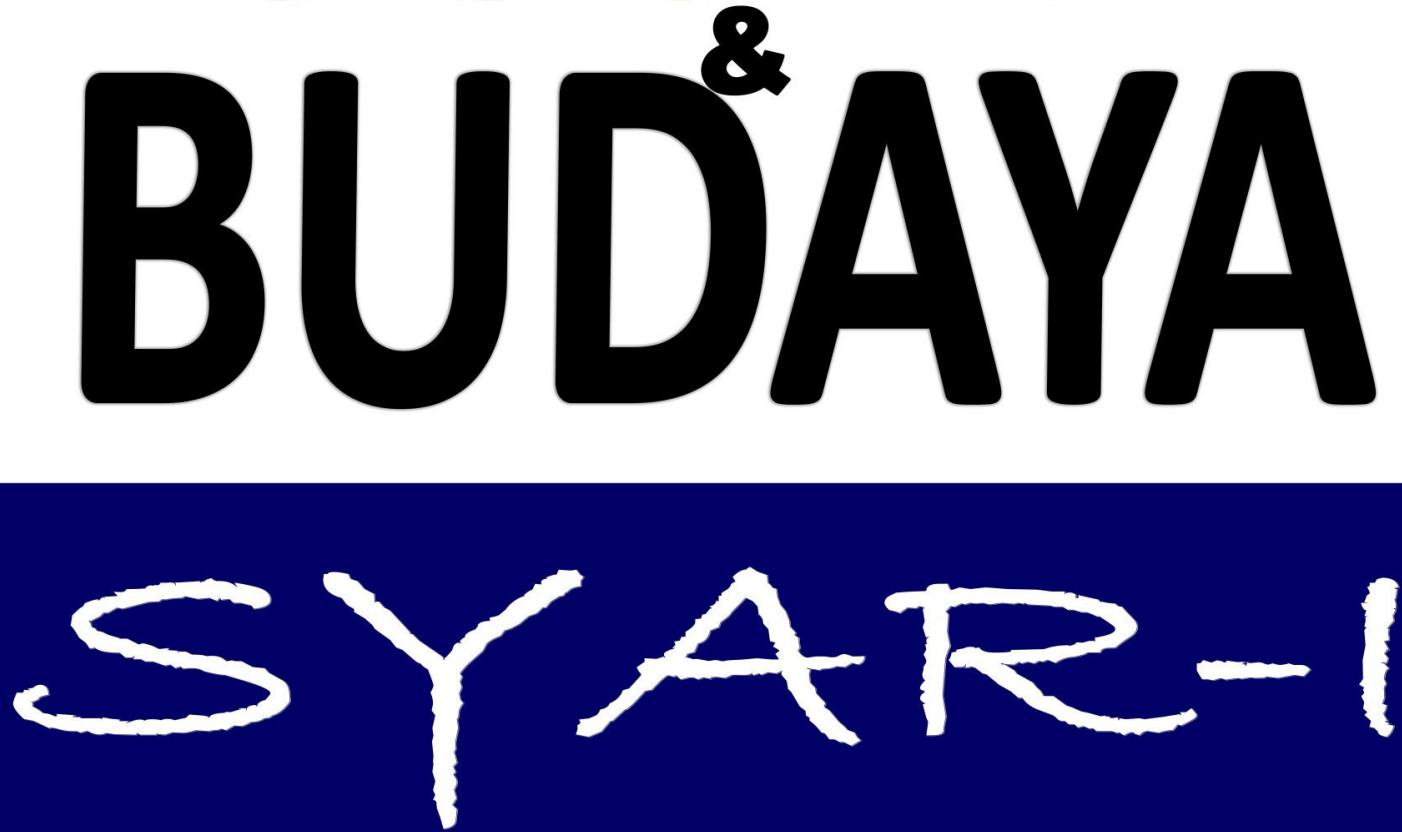

Bersama Melawan Virus Covid 19 di Indonesia

Syafrida \& Ralang Hartati

Optimalisasi Kebijakan Pemerintah dalam penanganan Covid-19 terhadap Masyarakat Indonesia Imas Novita Juaningsih, Yosua Consuello, Ahmad Tarmidzi \& Dzakwan Nurırfan

Kebijakan Pemberian Insentif Pada Tenaga Medis Virus Corona Covid-19 Pendekatan Maslahah Harisah

Budaya Media Sosial, Edukasi Masyarakat, dan Pandemi COVID-19

Muchammad Bayu Tejo Sampurno, Tri Cahyo Kusumandyoko \& Muh Ariffudin Islam

Covid-19 dan Hak Masyarakat atas Kesehatan

Siti Nurhalimah

Wabah Corona Virus Disease (Covid 19) Dalam Pandangan Islam

Eman Supriatna

Virus Corona Dampak dari Makanan yang tidak Halal

Faiqatul Husna 


\title{
Optimalisasi Kebijakan Pemerintah Dalam Penanganan Covid-19 Terhadap Masyarakat Indonesia*
}

\author{
Imas Novita Juaningsih, ${ }^{1}$ Yosua Consuello, ${ }^{2}$ Ahmad Tarmidzi, ${ }^{3}$ \\ Dzakwan NurIrfan ${ }^{4}$ \\ Universitas Islam Negeri Syarif Hidayatullah Jakarta \\ do \\ 10.15408/sjsbs.v7i6.15363
}

\begin{abstract}
Health insurance to the community has been manifested in the constitution of the Indonesian state. With this guarantee, the Indonesian people can have the same rights before the law for the welfare of their people. In responding to the existence of the COVID19 pandemic that has surrounded the world, one of them is Indonesia. Besides, the problem that occurs due to COVID-19 is that the coordination between the central and regional levels is not optimal which results in the spread of the COVID-19 virus in Indonesia. The foundation of the theory that I use is the theory of justice and the welfare state. Then the method used is juridical normative namely the method with the positivist legist approach with the law approach and comparative approach. So the need for policies that the government can provide so that COVID-19 can be resolved optimally.
\end{abstract}

Keyword: COVID-19, Government Policy, Justice

\begin{abstract}
Abstrak
Jaminan kesehatan terhadap masyarakat telah termanifestasikan dalam konstitusi negara Indonesia. Dengan adanya jaminan tersebut, maka masyarakat Indonesia dapat memiliki hak yang sama dimata hukum untuk tujuan mesejahterakan rakyatnya. Dalam menyikapi adanya pandemic Covid-19 yang telah mengelilingi dunia bahkan salah satunya adalah Indonesia. Disamping itu, problematika yang terjadi akibat adanya Covid-19 yaitu kurang optimal kordinasi antar pusat dan daerah yang berdampak semakin tersebarnya virus Covid-19 di Indonesia. Landasan teori yang penulis gunakan yaitu teori keadilaan dan walfare state. Kemudian metode yang digunakan adalah yuridis normatif yakni metode dengan pendekatan legis positivis dengan pendekatan undang-undang dan pendekatan komparasi (comparation apporoach). Maka perlu adanya kebijakan yang dapat pemerintah berikan agar Covid-19 dapat terselesaikan dengan optimal.
\end{abstract}

Kata Kunci: Covid- 19, Kebijakan Pemerintah, Keadilan

\footnotetext{
*Diterima: 14 April 2020, Revisi: 21 Mei 2020, Diterbitkan 31 Mei 2020.

${ }^{1}$ Imas Novita Juaningsih adalah Peneliti pada Pusat Studi Konstitusi dan Legislasi Nasional (Poskolegnas) UIN Jakarta.

2 Yosua Consuello adalah Peneliti pada Pusat Studi Konstitusi dan Legislasi Nasional (Poskolegnas) UIN Jakarta.

3 Ahmad Tarmidzi adalah Peneliti pada Pusat Studi Konstitusi dan Legislasi Nasional (Poskolegnas) UIN Jakarta.

4 Dzakwan NurIrfan adalah Peneliti pada Pusat Studi Konstitusi dan Legislasi Nasional (Poskolegnas) UIN Jakarta.
} 


\section{Pendahuluan}

Konstitusi negara Indonesia telah menjamin adanya jaminan kesehatan bagi warga negaranya, dengan terejawantahkan dalam Pasal 28H ayat (1) UUD NRI 1945. Artinya Pemerintah memiliki tanggung jawab untuk memperhatikan dan memberikan jaminan yang sesuai dengan amanat konstitusi. Karena warga negara Indonesia memiliki hak yang sama di mata hukum sesuai dengan Konsep Hak Asasi Manusia untuk memberikan keadilan dan mensejahterakan rakyatnya tanpa membeda-bedakan kelas sosial. Dengan adanya jaminan kesehatan yang diberikan oleh Pemerintah, maka jika terdapat permasalahan di negara ini seperti merebaknya Covid-19 dapat teratasi dengan adanya jaminan tersebut.

Secara historical context, Covid-19 merupakan penyakit menular yang mulai berkembang di tahun 2019 yang sampai saat ini menjadi permasalahan utama di seluruh dunia. Awal keberadaannya yaitu berasal dari Wuhan, Tiongkok yang disebabkan berasal dari salah satu hewan liar yaitu kelalawar. ${ }^{5}$ Dampak dari terkenanya Covid-19 bagi individu yang terinfeksi yaitu akan mengalami gangguan pernafasan ringan hingga dapat menyebabkan kematian. ${ }^{6}$

World Healt Organization melansir data yang berhasil menginfeksi 827.419 jiwa pada 203 negara dengan kasus sejumlah 827.419 dan dengan angka kematian 40.777 jiwa, yang menyebabkan 4.291 orang meninggal dunia. ${ }^{7}$ Dengan data yang telah terpublish di Media Sosial bahkan televisi yang dilihat oleh masyarakat menimbulkan kegelisahan yang sangat menghunjam kalangan masyarakat. Akibatnya sifat masyarakat yang tamak untuk membeli kebutuhan sehari-hari menjadi pemicu utama keretakan dari asas gotong royong, bahkan di saat merebaknya Covid-19 masih ada kalangan yang meraup keuntungan sebesar-besarnya dengan menimbun maskermasker yang telah disediakan untuk diperjualbelikan dengan harga yang tinggi.

Dalam penangan Covid-19, kebijakan pemerintah justru mengalami disharmonisasi antara Kebijakan yang dibuat oleh pemerintah pusat dengan kebijakan Pemerintah Daerah. Perbedaan tersebut dimulai ketika beberapa daerah menetapkan Lockdown ${ }^{8}$ namun pemerintah pusat menetapkan Pembatasan Sosial Berskala Besar (PSBB). ${ }^{9}$ Kebijakan yang diterapkan oleh Pemerintah Pusat yang masih menjadi

5 Yuliana, Corona virus diseases (Covid-19); sebuah tinjuan literature, Jurnal Wellness and Healthy Magazine Vol 2, No. 1, Februari 2020, hlm. 188.

6 "Covid-19 Coronaviruses Pandemic," 15 Maret 2020 , https://www.worldometers.info/coronavirus/; Wang Zhou, ed., Coronavirus Prevention Handbook (Wuhan: Hubei Science and Technology Press, 2020).

7 World Health Organization, “Coronavirus," last modified 2020, 15 Maret 2020, https://www.who.int/health-topics/coronavirus\#tab=tab_1.

${ }^{8}$ Lockdown atau karantina wilayah merupakan penerapan karantina terhadap suatu daerah atau wilayah tertentu dalam rangka mencegah perpindahan orang, baik masuk maupun keluar wilayah tersebut, untuk tujuan tertentu yang mendesak. Kebijakan lockdown ini diterapkan oleh sebuah negara yang mengalami keadaan darurat seperti perang atau wabah penyakit yang menular. Kemudian istilah ini banyak dikenal akibat adanya pandemi penyakit koronavirus 12019 yang tersebar di berbagai negara secara massif.

${ }_{9}$ PSBB atau Pembatasan Sosial Berskala Besar merupakan istilah karantina kesehatan di Indonesia yang didefinisikan sebagai "pembatasan kegiatan tertentu penduduk dalam suatu wilayah yang diduga 
kejanggalan di kalangan masyarakat, karena himbauan yang dibuat masih bersifat tidak mengikat. Seolah Pemerintah Pusat tidak mau merugi dengan tidak diterapkannya lockdown.

Maka berdasarkan legal remerendum tersebut, penulis menghasilkan permasalahan dalam penelitian ini, yaitu bagaimana kebijakan pemerintah dalam menangani covid-19, apakah sudah berjalan dengan efektif karena mengingat tujuan dari negara yaitu untuk menyejahterakan rakyatnya. Maka perlu langkah atau gagasan yang dapat mengoptimalkan kebijakan pemerintah sesuai dengan implementasi yang ada pada masyarakat.

\section{Metode Penelitian}

Penelitian dalam tulisan ini adalah penelitian hukum yuridis-normatif. Penulisan yuridis-normatif atau penelitian hukum normatif merupakan penelitian kepustakaan, yaitu penelitian terhadap data sekunder. ${ }^{10}$ Penelitian ini juga melakukan pendekatan konsep (conseptual approach), ${ }^{11}$ dan pendekatan komparatif (comparative approach). ${ }^{12}$ Pendekatan konsep (conseptual approach) dilakukan hingga ditemukan suatu upaya pembenahan dan pendekatan baru guna menanggulangi permasalahan yang ada. Sedangkan komparatif (comparative approach) adalah jenis penelitian deskriptif yang ingin mencari jawaban secara mendasar tentang sebab-akibat, dengan menganilisis faktor-faktor penyebab terjadinya ataupun munculnya suatu fenomena tertentu. Jadi penelitian komparatif adalah jenis penelitian yang digunakan untuk membandingkan antara dua kelompok atau lebih dari suatu variabel tertentu. ${ }^{13}$

\section{Teori Negara dan Welfare State}

Pada hakikatnya negara menurut Roger F. Soleau merupakan sebuah sarana atau dapat disebut sebuah wewenang yang mengendalikan dan mengatur masalahmasalah yang bersifat umum dalam kehidupan masyarakat. ${ }^{14}$ Berangkat dari poros pemikiran tersebut, untuk itu perlunya juga memahami dan menggali lebih jauh mengenai tujuan dari negara itu sendiri, agar dapat dipahami orientasi dan motivasi terbentuknya negara dan kearah mana cita-cita yang hendak diwujudkannya. Sudah menjadi barang tentu hal yang sangat diimpikan oleh seluruh negara yakni dapat memberikan perlindungan, rasa aman, dan yang paling penulis garisbawahi adalah kesejahteraan dan kemakmuran rakyat sebesar-besarnya. Karena itulah seluruh negara

terinfeksi penyakit dan/atau terkontaminasi sedemikian rupa untuk mencegah kemungkinan penyebaram penyakit. PSBB ini salah satu jenis penyelenggaraan kekarantinaan kesehatan di wilayah, selain karantina rumah, karantina rumah sakit, dan karantina wilayah. Tujuannya yaitu mencegah meluasnya penyebaran penyakit kedaruratan kesehatan masyarakat yang sedang terjadi antar orang disuatu wilayah tertentu.

10 Romy Hanitijo Soemito, 1998, Metodologi Penelitian Hukum dan Jurimetri, Jakarta: Ghalia Indonesia, hlm. 11.

${ }^{11}$ Peter Mahmud Marzuki, 2005, Penelitian Hukum, Jakarta: Prenadamedia Group, hlm. 133.

12 Sugiyono, 2006, Metode Penelitian Kuantitatif, Kualitatif dan RED, Bandung: Alfabeta, hlm. 68.

${ }^{13}$ Nazir, 2005, Metode Penelitian, Jakarta: Ghalia Indonesia hlm. 58.

${ }^{14}$ https://www.zonareferensi.com/pengertian-negara/ 
berlomba-lomba untuk membangun sebuah negara kesejahteraan (Welfare State) yang dikemukakan pertama kali oleh Kaisar Ashoka di India pada abad ke 3 SM. Teori ini kemudian dianut sekaligus disempurnakan oleh R. Kranenburg. Welfare state sendiri berorientasi pada kesejahteraan umum. Dalam hal ini negara dipandang sebagai alat belaka yang dibentuk manusia untuk mencapai tujuan bersama, kemakmuran, dan keadilan sosial bagi seluruh rakyat tersebut. ${ }^{15}$

\section{Teori Keadilan}

Secara historical konteks pengkajian terhadap keadilan telah dilakukan sejak masa Yunani Kuno. Konsep keadilan pada masa itu berasal dari pemikiran tentang sikap atau perilaku manusia terhadap sesamanya dan terhadap alam lingkungannya, artinya manusia harus memanusiakan dan berbuat adil terhadap sesamanya begitu juga manusia dengan alam sekitarnya. ${ }^{16}$ Kalau dikaji dalam konteks kenegaraan, negara sebagai organisasi kekuasaan memilik peran fundamental dalam pemenuhan kebutuhan, terutama kebutuhan pokok untuk menghadapi Corona Virus Disease 2019 (COVID- 19).

Penulis berpendapat dalam situasi seperti ini negara harus hadir dalam memberikan berbagai bantuan yang dibutuhkan oleh seluruh lapisan masyarakat tanpa terkecuali, mengingat dampak yang ditimbulkan oleh keganasan virus ini masif dan memberikan efek pelumpuhan pada jalannya roda perkonomian hampir di seluruh sektor. Hal ini pun diamini oleh Aristoteles sebagai seorang filsuf beraliran mazhab klasik, di mana ia menekankan teorinya pada perimbangan atau proporsi Menurutnya di dalam negara segala sesuatunya harus diarahkan pada cita-cita yang mulia yaitu kebaikan dan kebaikan itu harus terlihat lewat keadilan dan kebenaran. Penekanan perimbangan atau proporsi pada teori keadilan Aristoteles, dapat dilihat dari apa yang dilakukannya bahwa kesamaan hak itu haruslah sama diantara manusia yang sama. ${ }^{17}$

\section{Pembahasan}

\section{Kebijakan Pemerintah dalam kaca mata Konstitusi}

Pembatasan Sosial Berskala Besar (PSBB) merupakan kebijakan pemerintah yang dikeluarkan melalui Peraturan Pemerintah Nomor 21 Tahun 2020 tentang Pembatasan Sosial Berskala Besar Dalam Rangka Percepatan Penanganan Corona virus Disease 2019 (COVID-19). Pembatasan Sosial Berskala Besar (PSBB) adalah pembatasan kegiatan tertentu penduduk dalam suatu wilayah yang diduga terinfeksi Corona Virus Disease 2019 (COVID-19) sedemikian rupa untuk mencegah kemungkinan penyebaran Corona Virus Disease 2019 (COVID-19). Kebijakan tersebut merupakan implementasi dari pembukaan Undang-Undang Dasar Republik Indonesia alinea ke-4 “Kemudian dari pada

15 Linbeck, A, 2006, The Welfare State Background, Achievementse, Problem, Research Institute of Industrial Economics, hlm. 32.

16 Nursyam Mohammad. 1998. "Penjabaran Filsafat Pancasila Dalam Filsafat Hukum. Sebagai Landasan Pembinaan Hukum Nasional”. Disertasi. Universitas Airlangga Surabaya, hlm. 21.

17 Rapar J.H, 1991, Filsafat Politik Plato. Jakarta: Rajawali Press, hlm. 21. 
itu untuk membentuk suatu Pemerintahan Negara Indonesia yang melindungi segenap bangsa Indonesia dan seluruh tumpah darah Indonesia dan untuk memajukan kesejahteraan umum..." dapat dimaknai dari pembukaan Undang-Undang Dasar Negara Republik Indonesia Tahun 1945 negara harus melindungi segenap bangsa Indonesia yang diimplementasikan melalui Pembatasan Sosial Berskala Besar untuk mengurangi penyebaran Corona Virus Disease 2019 (COVID-19).

Pembatasan Sosial Berskala Besar ini didasari dari beberapa aturan dasar, Undang-Undang Nomor 4 Tahun 1984 tentang Wabah Penyakit Menular, ${ }^{18}$ UndangUdang Nomor 24 Tahun 2007 tentang Penanggulangan Bencana ${ }^{19}$, serta UndangUndang Nomor 6 Tahun 2018 tentang Kekarantinaan Kesehatan. ${ }^{20}$ Pasal 2 UndangUndang Nomor 4 Tahun 1984:

"Maksud dan tujuan Undang-Undang ini adalah untuk melindungi penduduk dari malapetaka yang ditimbulkan wabah sedini mungkin, dalma rangka meningkatkan kemampuan masyarakat untuk hidup sehat."

Dalam hal ini Pasal 2 Undang-Undang Nomor 4 Tahun 1984 dapat dijadikan dasar tujuan penerapan Pembatasan Sosial Berskala Besar, yang pada intinya bertujuan untuk mengurangi penyebaran wabah atau pandemi Corona Virus Disease 2019 (COVID19) agar melindungi masyarakat dari pada wabah atau pandemi yang sangat berbahaya ini. Termaktub pula dalam Pasal 5 ayat (1) Undang-Undang Nomor 4 Tahun 1984 yang disebutkan:

(1) Upaya penanggulangan wabah meliputi: a) Penyelidikan epidemiologis; b) Pemeriksaan, pengobatan, perawatan, dan isolasi penderita, termasuk tindakan karantina; c) Pencegahan dan pengebalan; d) Pemusnahan penyebab penyakit; e) Penanganan jenazah akibat wabah; f) Penyuluhan kepada masyarakat; g) Upaya penanggulangan lainnya.

Secara implisit Pembatasan Sosial Berskala Besar termaktub pada Pasal 5 Ayat (1) Undang-Undang Nomor 4 Tahun 1984 yang berisi tentang bagaimana upaya penanggulangan sebuah wabah.

Pasal 4 Undang-Undang Nomor 24 Tahun 2007 tentang Penanggulangan Bencana dijelaskan apa tujuan dalam penanggulangan bencana itu.

Penanggulangan bencana bertujuan untuk: a) Memberikan perlindungan kepada masyarakat dari ancaman bencana; b) Menyelarskan peraturan perundang-undangan yang sudah ada; c) Menjamin terselenggaranya penanggulangan bencana secara terencana, terpadu, terkoordinasi, dan menyeluruh; d) Menghargai budaya lokal; e) Membangun partisipasi dan kemitraan publik serta swasta; f) Mendorong semangat

18 Lihat dalam Undang-undang No. 4 Tahun 1984 tentang penyakit wabah menular (Lembaran Negara Republik Indonesia Tahun 1984 Nomor 20, Tambahan Lembaran Negara Republik Indonesia Nomor 3273)

${ }^{19}$ Lihat dalam Undang-undang No. 24 Tahun 2007 Tentang Penanggulangan Bencana (Lembaran Negara Tahun 2007 Nomor 66, Tambahan Lembaran Negara Republik Indonesia Nomor 4723)

${ }^{20}$ Lihat dalam Undang-undang No. 6 Tahun 2018 tentang Karantina Kesehatan( Lembaran Negara Republik Indonesia Tahun 2018 Nomor 128, Tambahan Lembaran Negara Republik Indonesia Nomor 6236) 
gotong royong, kesetiakawanan, dan kedermawanan; dan g) Menciptakan perdamaian dalam kehidupan bermasyarakat, berbangsa dan bernegara.

Pembatasan Sosial Berskala Besar didasarkan dari beberapa Undang-Undang yang memiliki satu tujuan yang sama, yaitu untuk keselamatan masyarakat dari bencana, wabah ataupun pandemi yang sekarang terjadi di Indonesia. Dalam pelaksanaan Pembatasan Sosial Berskala Besar yang bertanggung jawab melaksanakannya tidak hanya pemerintah, namun juga seluruh rakyat harus menjalankan Pembatasan Sosial Berskala Besar tersebut.

Selain Undang-Undang yang disebutkan di atas Pembatasan Sosial Berskala Besar-pun diatur secara rinci di dalam Peraturan Pemerintah Nomor 21 Tahun 2020 tentang Pembatasan Sosial Berskala Besar Dalam Rangka Percepatan Penanganan Corona Virus Disease 2019 (COVID-19). Pada praktiknya Pembatasan Sosial Berskala Besar ini memiliki kriteria antara lain:

a. Jumlah kasus dan/atau jumlah kematian akibat penyakit meninggal dan menyebar secara signifikan dan cepat ke beberapa wilayah; dan

b. Terdapat kaitan epidemiologis dengan kejadian serupa di wilayah atau negara lain.

Kasus pendemi ini masih terus meningkat di Indonesia, sama halnya dengan Malaysia dan Thailand. Sementara itu negara yang telah berhasil menekan angka sebaran di antaranya China dan Korea Selatan. Grafik berikut ini menunjukkan bagaimana sebaran pandemi di China dan Korea Selatan. ${ }^{21}$

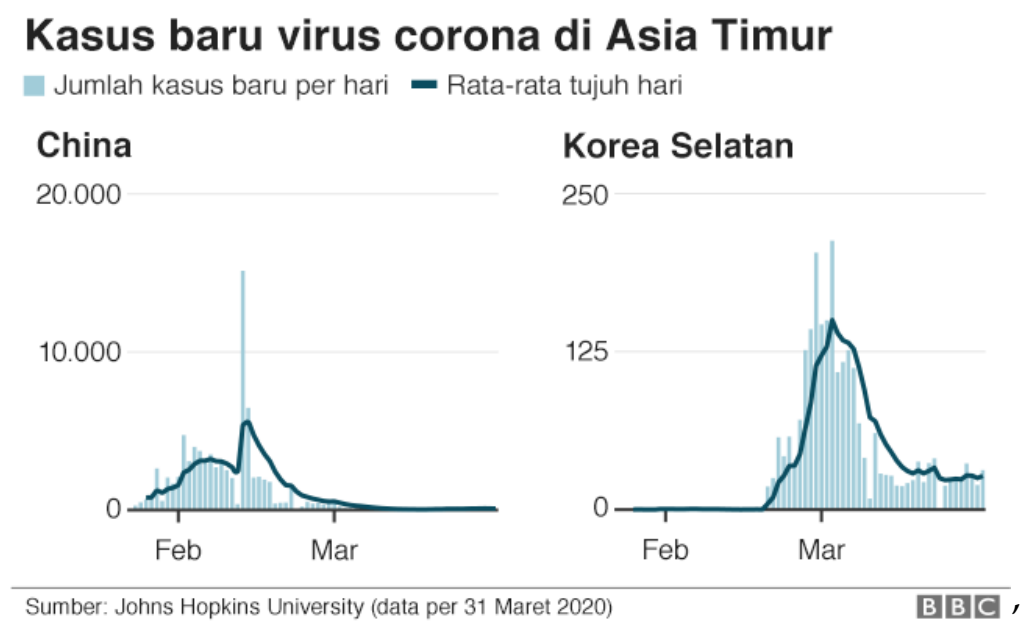

Gambar 1.1

Grafik di atas adalah bagaimana Pembatasan Sosial Berskala Besar di Korea Selatan dapat menekan angka penularan yang sangat signifikan. Pada praktiknya di Pembatasan Sosial Berskala Besar merupakan hal yang efektif bila diterapkan di

${ }^{21}$ Agnia Adzkia, https://www.bbc.com/indonesia/indonesia-52153187 , (diakses Kamis, 16 April 2020, Pukul 16.17 WIB) 
Indonesia. Bahkan pemerintah Korea memilih untuk memperpanjang Pembatasan Sosial Berskala Besar yang telah dilaksanakannya sejak 20 Januari lalu. ${ }^{22}$

Indonesia dapat menerapkan Pembatasan Sosial Berskala Besar dengan berkaca dari Korea Selatan, dengan menjaga jarak sosial setidaknya dua meter satu sama lain bila berpapasan atau sedang mengantri di dalam sebuah toko dan membatasi orang untuk pergi keluar rumah bila dibutuhkan saja. ${ }^{23}$

\section{Hak Jaminan Masyarakat sebagai Manifestasi Hak Konstitusional}

Jaminan masyarakat juga bisa disebut dengan jaminan sosial pada dasarnya dilaksanakanan sesuai dengan prinsip negara kesejahteraan (Welfare State) yang berkembang luas di beberapa negara seperti negara-negara Eropa Barat, Amerika Serikat, Australia dan Selandia Baru. ${ }^{24}$ Secara formal bila dilihat dalam Amandemen UUD 1945 Pasal 28 dan 34 mengamanatkan jaminan sosial dari negara. Pada dasarnya Jaminan sosial merupakan hak yang dimiliki rakyat dan harus dipenuhi oleh negara sesuai amanat konstitusi. ${ }^{25}$

Dalam Pasal 34 ayat (2) Undang-Undang Dasar 1945 berbunyi "Negara mengembangkan sistem jaminan sosial bagi seluruh rakyat dan memberdayakan masyarakat yang lemah dan tidak mampu sesuai dengan martabat kemanusiaan" artinya Negara harus mengoptimalkan jaminan sosial untuk seluruh lapisan masyarakat dan mencerminkan keadilan. Di tengah pandemi COVID-19 saat ini nampaknya berimbas pada semua sektor terutama ekonomi. Bank Dunia memproyeksikan pertumbuhan ekonomi Indonesia di tahun ini akan tertekan di level 2,1 persen. Hal ini disebabkan oleh terus meluasnya persebaran Covid-19 baik di dalam negeri maupun luar negeri. Bank Indonesia (BI) pun telah merevisi proyeksi pertumbuhan ekonomi RI menjadi di bawah 5 persen atau hanya sekitar 2,5 persen saja yang biasanya mampu tumbuh mencapai 5,02 persen. ${ }^{26}$

Dalam hal ini perlu diperhatikan penangananan kesehatan masyarakat seperti penyediaan alat-alat kesehatan, treatment pasien, riset vaksin dan obat, serta pencegahan wabah yang terus menyebar. Pemerintah telah mengambil berbagai langkah pengamanan seperti, physical distancing, work and study from home, pembatasan/pelarangan kegiatan publik, testing, tracing, dll. Namun hal-hal tersebut belum mencukupi untuk mencegah terjadi krisis kesehatan dalam pandemi sekarang

\footnotetext{
22 https://www.cnnindonesia.com/internasional/20200404200011-113-490356/dinilai-efektif-korselperpanjang-masa-social-distancing, diakses Kamis, (16 April 2020, Pukul 16.08 WIB)

23 Miranti Kencana Wirawan, Korea Selatan Umumkan Perpanjangan Soscial Distancing, https://www.kompas.com/global/read/2020/04/05/220306570/korea-selatan-umumkan-perpanjangansocial-distancing?page=all , (diakses hari Kamis, tanggal 16 April 2020, Pukul 16.20)

${ }^{24}$ James Midgley, 1997, Social Welfare in Global Context. London: Sage Publication.

${ }^{25}$ Sentanoe Kertonoegoro, 1987, Jaminan Sosial dan Plekasannnya di Indonesia, Cet. II Mutiara Sumber Widya, Jakarta, hlm. 7.

26 Nabila Nurul Putri, "Dampak Pandemi Corona Terhadap Sektor Ekonomi Indonesia", https://sukabumiupdate.com/detail/bale-warga/opini/67504-Dampak-Pandemi-Corona-Terhadap-SektorEkonomi-Indonesia. (diakses pada 15 April 2020, pukul 22.16).
} 
ini. Atas dasar inilah Pemerintah melakukan tindakan berupa kebijakan pembatasan sosial berskala besar (PSBB) untuk mengurangi penyebaran Covid-19 saat ini yang diatur dalam Permenkes 9 Tahun 2020 tentang Pedoman PSBB dalam rangka Percepatan Penanganan Covid-19. Dalam peraturan tersebut, Pembatasan Sosial Berskala Besar adalah pembatasan kegiatan tertentu penduduk dalam suatu wilayah yang diduga terinfeksi Corona Virus Desease 2019 (Covid-19).

Pembatasan Sosial Berskala besar paling sedikit meliputi, perliburan sekolah dan tempat kerja, pembatasan kegiatan kegamaan dan/atau pembatasan kegiatan di tempat atau fasilitas umum. Berdasarkan Pasal 4 ayat (3) Peraturan Pemerintah nomor 21 Tahun 2020 tentang Pembatasan Sosial Berskala Besar dalam Rangka Percepatan Penanganan Corona Virus yang berbunyi "pembatasan kegiatan sebagaimana dimaksud pada ayat (1) huruf c dilakukan dengan memerhatikan pemenuhan kebutuhan dasar penduduk". Artinya, disaat pemerintah memberlakukan kebijakan PSBB harus memerperhatikan pemenuhan kebutuhan dasar penduduk juga.

Maka, untuk menjamin ketersediaan kebutuhan pokok masyarakat pemerintah memberlakukan enam paket kebijkan yang juga dapat membantu masyarakat lapisan bawah yang terdampak COVID-19. Keenam paket kebijakan itu antara lain:

1) Penerima bantuan Program Keluarga Harapan atau PKH naik dari 9,2 juta menjadi 10 juta keluarga dengan besaran dana yang naik $25 \%$.

2) Menaikkan jumlah penerima Kartu Sembako dari 15,2 juta menjadi 20 juta penerima manfaat. Nilai bantuannya juga naik dari Rp 150 ribu menjadi Rp 200 ribu. Kebijakan ini akan diberikan selama sembilan bulan.

3) Kebijakan kartu prakerja anggarannya dinaikkan dari Rp 10 triliun menjadi Rp 20 triliun, dengan jumlah penerima 5,6 juta orang. Kebijakan diutamakan untuk pekerja informal dan pelaku usaha mikro dan kecil yang terdampak COVID-19. Nilai yang diberikan Rp 650-RP 1 juta perbulan selama empat bulan ke depan.

4) Pemerintah menggratiskan listrik untuk pengguna $450 \mathrm{VA}$ yang jumlahnya sampai 24 juta pelanggan. Kebijakan ini berlaku selama tiga bulan ke depan terhitung sejak April-Juni 2020. Sedangkan untuk pelanggan 900 VA yang jumlahnya sekitar tujuh juta pelanggan mendapatkan diskon $50 \%$.

5) Pemerintah telah mencadangkan Rp 25 triliun untuk pemenuhan kebutuhan pokok, operasi pasar, dan logistik.

6) Pemerintah memastikan keringanan pembayaran kredit bagi pekerja infromal tetap berlaku. Pekerja infromal yang dimaksud seperti ojek daring, sopir taksi, pelaku UMKM, nelayan, dan lain-lain dengan penghasilan harian dan kredit dibawah Rp 10 miliar. ${ }^{27}$

Kebijakan-kebijakan pemerintah diatas, sebagai langkah pemerintah dan juga untuk menjamin hak-hak masyarakat seperti hak ekonomi, kesehatan, dll dalam menghadapi pandemi COVID-19. Pemerintah juga diperlukan untuk melakukan tes massal dengan sensitivitas mendekati 100\% yakni tes Polymerase Chain Reaction (PCR).

27 Akbar Ridwan, “Pemerintah harus jamin kebutuhan pokok masyarakat terpenuhi saat PSBB”, https://www.alinea.id/nasional/pemerintah-harus-jamin-kebutuhan-pokok-terpenuhi-saat-psbbb1ZLh9sVp, (diakses pada 16 April 2020, pukul 03.39). 
Pemerintah Indonesia menargetkan bisa melakukan 10.000 tes Polymerase chain reaction (PCR) virus corona (Covid-19) per hari, guna membendung penyebaran penyakit mematikan ini. ${ }^{28}$

\section{Kesimpulan}

Jaminan kesehatan setiap warga negara Indonesia telah termatub dalam konstitusi. Dengan adanya jaminan kesehatan yang diberikan oleh Pemerintah, maka pemerintah memiliki tanggung jawab terhadap warga negaranya terlebih dalam permasalahan pandemi Covid-19. Oleh karena itu, untuk mencapai setidaknya cita-cita negara yaitu negara kesejahteraan (welfare state), pemerintah perlu memberlakukan kebijakan yang dapat menjadi solusi dari permasalahan yang ada. Dengan menerapkan Pembatasan Sosia Berskala Besar (PSBB) merupakan langkah preventif yang saat ini sedang pemerintah terapkan.

Karena masih banyak masyarakat yang kurangnya pemahaman terhadap hal ini, maka salah satu usulan penulis yang paling tepat untuk terlaksananya Pembatasan Sosial Berskala Besar yaitu dengan memberikan beberapa sosialisasi yang dilakukan oleh tingkat pusat kepada pemerintah daerah hingga tingkat RT dan penerapan sanksi tegas kepada masyarakat yang tidak mau tertib dalam melaksanakan Pembatasan Sosial Berskala Besar. Selain memaksimalkan tes massal seperti Korea Selatan, dan memberikan subsidi listrik kepada masyarakat $50 \%$.

\section{Referensi:}

A, L. (2006). The Welfare State Background, Achievements, Problem. Research Institute of Industrial Economics.

Adzkia, A. (2020, April 16). Retrieved from https://www.bbc.com/indonesia/indonesia52153187

Hastuti, R. K. (n.d.). CNBC. Retrieved from https://www.cnbcindonesia.com/news/20200415160224-4-152163/agresifpemerintah-targetkan-10000-tes-pcr-per-hari,

J.H, R. (1991). Filsafat Politik Plato. Jakarta: Rajawali Press.

Kertonoegoro, S. (1987). Jaminan Sosial dan Pelaksanaannya di INdonesia. Jakarta: Mutiara Sumber Widya.

Marzuki, P. M. (2005). Penelitian Hukum. Jakarta: Prenadamedia Group.

Midgley, J. (1997). Social Welfare in Global Contect. London: Sage Publication.

28 Rahajeng Kusumo Hastuti, "Agresif! Pemerintah Targetkan 10.000 Tes PCR per Hari”, https://www.cnbcindonesia.com/news/20200415160224-4-152163/agresif-pemerintah-targetkan-10000-tespcr-per-hari, (diakses pada 16 April 2020, pukul 03.53) 
Mohammad, N. (1998). Penjabaran Filsafat Pancasila dalam Filsafat Hukum sebagai Landasan Pembinaan Hukum Nasional. Disertasi: Universitas Airlaga Surabaya.

Nazir. (2005). Metode Penelitian. Jakarta: Ghalia Indonesia.

Organization, W. H. (n.d.). Retrieved from https://www.who.int/healthtopics/coronavirus\#tab=tab_1.

Putri, N. N. (n.d.). Retrieved from https://sukabumiupdate.com/detail/balewarga/opini/67504-Dampak-Pandemi-Corona-Terhadap-Sektor-EkonomiIndonesia.

Ridwan, A. (n.d.). Alinea. Retrieved from https://www.alinea.id/nasional/pemerintahharus-jamin-kebutuhan-pokok-terpenuhi-saat-psbb-b1ZLh9sVp,

Soemito, R. H. (1998). Metodologi Penelitian Hukum dan Jurimetri. Jakarta: Ghalia Indonesia.

Sugiyono. (2006). Metode Penelitian Kuantitatif, Kualitatif dan RED. Bandung: Alfabeta.

Wirawan, M. K. (n.d.). Kompas. Retrieved from https://www.kompas.com/global/read/2020/04/05/220306570/korea-selatanumumkan-perpanjangan-social-distancing?page=all

Yuliana. (2020). Corona Virus Diseases (Covid 19); sebuah tinjauan literature. Jurnal WellNess and Healthy Magazine, 2(1), 188.

Zhou, W. (2020). Coronavirus Prevention Handbook. Wuhan: Hubei Science and Technology Press.

Buana, Dana Riksa, "Analisis Perilaku Masyarakat Indonesia dalam Menghadapi Pandemi Virus Corona (Covid-19) dan Kiat Menjaga Kesejahteraan Jiwa," Salam: Jurnal Sosial dan Budaya Syar-i, Volume 7, No. 3 (2020).

Yunus, N.R.; Rezki, Annissa. "Kebijakan Pemberlakuan Lock Down Sebagai Antisipasi Penyebaran Corona Virus Covid-19," Salam: Jurnal Sosial dan Budaya Syar-i, Volume 7, No. 3 (2020). 


\section{Indexed by :}
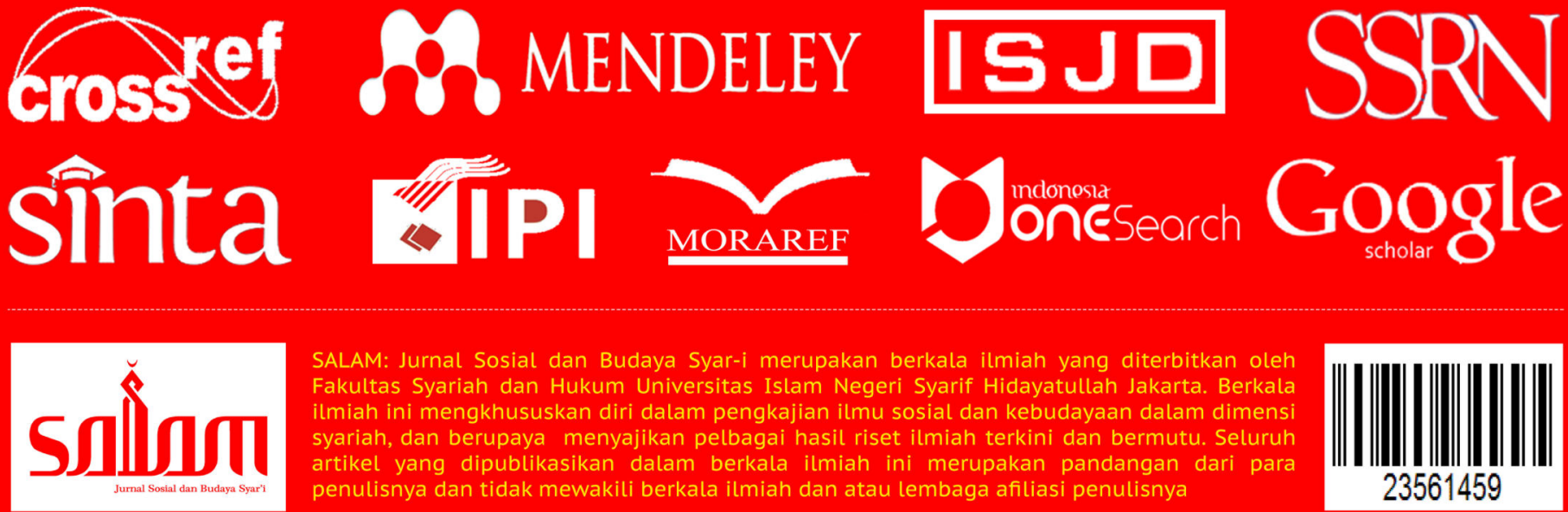

SALAM: Jurnal Sosial dan Budaya Syar-i merupakan berkala ilmiah yang diterbitkan oleh Fakultas Syariah dan Hukum Universitas Islam Negeri Syarif Hidayatullah Jakarta. Berkala ilmiah ini mengkhususkan diri dalam pengkajian ilmu sosial dan kebudayaan dalam dimensi syariah, dan berupaya menyajikan pelbagai hasil riset ilmiah terkini dan bermutu. Seluruh artikel yang dipublikasikan dalam berkala ilmiah ini merupakan pandangan dari para penulisnya dan tidak mewakili berkala ilmiah dan atau lembaga afiliasi penulisnya

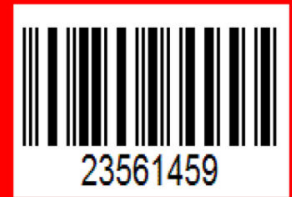

